R I C H A R D N. COOPER

Harvard University

\title{
Living with Global Imbalances
}

OVER THE YEARs, the Brookings Panel has focused overwhelmingly on the U.S. economy. That emphasis reflected the principal interests of its founders, Arthur Okun and George Perry. The United States is by far the largest economy in the world, accounting for a quarter to a third of global output, so understanding the U.S. economy is important. And this economy is rich in data. But that still leaves over two-thirds of the world economy. The Brookings Papers has made excursions into this area from time to time. At various points Europe, Japan, and most recently China have been addressed. There was a flurry of interest in the transition economies some years ago, in the international financial crises of the mid- to late 1990s, and more rarely in developing countries more broadly.

The U.S. economy and the economies of the rest of the world intersect through international transactions. These have received more attention in the Brookings Papers, although again largely with a U.S. focus. I will address this intersection with respect to the large global imbalances that exist today, although I will deviate from the usual practice here by adopting a rest-of-the-world rather than a U.S. perspective.

In this brief paper I want to cast doubt on two related propositions that are widely accepted as truths: that Americans save too little, and that the U.S. current account deficit is unsustainably large, risking a disorderly adjustment that would be damaging to the world economy in the relatively near (but usually unspecified) future. These remarks should not be treated as new truths, but as plausible alternative hypotheses about how the world works these days, how we reached our current circumstances, and what the future may bring. 


\section{U.S. National Saving in Perspective}

I begin with U.S. saving because I will say less about it. The question of whether Americans save enough relates to the broader topic of global imbalances through the national accounts identity linking the current account deficit to the difference between domestic investment and national saving. A current account deficit cannot be reduced without reducing the excess of investment over saving. Few argue that the United States should invest less (except perhaps in housing during the housing boom, or in routers and fiberoptic cable in the technology boom), which implies that if the U.S. current account deficit, around 6 percent of GDP in recent years, is to be reduced, national saving - the sum of private and public savingmust be increased. If, as some analysts suggest, ${ }^{1}$ the current account deficit should not exceed 3 percent of GDP, and if investment is to be protected, then saving must increase by 3 percent of GDP, or from 13 percent of GDP to 16 percent in terms of 2006 shares. I will refer to gross saving and investment throughout, as is appropriate in a world of rapid technological change. "Replacement" investment is typically technologically superior to its predecessor, and in any case a well-run firm will evaluate all large investments afresh, moving depreciation allowances into new activities if that is economically appropriate. Thus gross saving can be considered as available for new allocation.

The U.S. current account deficit has grown over the last decade or so, from 1.5 percent of GDP in 1995 to 6.1 percent in 2005 and 2006. ${ }^{2}$ Such growth implies a widening gap between saving and investment. Investment rose in the late 1990s, as did government saving as the federal budget moved into surplus; meanwhile private saving declined. In the early 2000s investment declined, but public saving declined even more, by an extraordinary 6 percent of GDP between 2000 and 2004, as a result of recession, federal tax cuts in 2001 and 2003, and increased expenditure for the military, for homeland security, and under other headings. Private saving recovered somewhat with the growth in corporate earnings from 2001 to 2005 , despite a continued decline in recorded household saving.

1. See, for example, Cline (2005).

2. U.S. current account and international investment position data are from the Bureau of Economic Analysis international accounts. 
Ratios of U.S. saving and investment to GDP have been below those in other rich countries and in some poor countries for many years. That the U.S. economy continues to grow robustly is testimony to the relative efficiency with which Americans use capital—or perhaps in part to the inappropriate conventions economists use to measure investment and saving.

Saving and investment in the national accounts, which were designed over sixty years ago at the height of the industrial age, are defined largely in terms of structures and equipment (although computer software was recently added). This is hardly appropriate for a so-called knowledge economy. Economists conceive of saving as consumption that is deferred today for the sake of greater consumption at some time in the future, perhaps by oneself, perhaps by future generations. On this definition, several items should be added to "saving" as currently recorded in the national accounts. Among the obvious ones are educational expenditure, expenditure on research and development, and purchases of consumer durables. Another item, not officially included in GDP, is intangible investment by businesses in training and in company and product branding. ${ }^{3}$ Adding these items to saving and investment for 2005 raises those quantities from 14 and 20 percent of GDP, respectively, as defined in the national accounts, to 39 and 44 percent (after also augmenting GDP by 15 percent to allow for the addition of intangible investment). These figures do not suggest that Americans are shorting the future, particularly when allowance is made for the high returns to education and to research and development. Recent poll results notwithstanding, it is extremely improbable that future Americans will be worse off than the current generation in material terms. So far as I can tell, the pipeline of prospective innovations is full; it would take a severe catastrophe for these, and the associated investment, not to mature into higher income per capita, as they have steadily done during the past half century. This generation's biggest legacy to the next is a successful apparatus - both institutions and incentives-for technical change and innovation.

From the perspective of the household, allowance should also be made for capital gains on real and financial assets, which can increasingly be mobilized for reinvestment thanks to innovations in financial markets such

3. Following Corrado, Hulten, and Sichel (2006). 
as home equity loans and reverse mortgages, and for expected legacies. Unlike new investment, these do not add to social returns in the future (although some part of capital gains on equities may reflect the intangible investments made by corporations), but they legitimately count as "saving" from a household's perspective. And they make a huge difference for total household wealth. Household net worth rose by 6.5 percent a year over 1990-2005, and by 8 percent in 2005 alone-a year when negative personal rates of saving as recorded in the national accounts grabbed the financial headlines. Of course, these are aggregate figures; they do not address the distribution of saving across households. Doubtless many families would be well advised to save more in their own interest.

The revised calculations of saving and investment above do not affect the discrepancy between the two, since saving and investment are raised by the same amount. I draw attention to them to suggest, rather, that it will be difficult if not impossible to raise U.S. national saving further, except through the federal budget. Private saving may rise of its own accord if house prices decline or stabilize for any length of time; but households are not likely to be quick to acknowledge the need to reduce their consumption.

What does all this mean for today's global imbalances? Can a U.S. current account deficit in excess of $\$ 800$ billion a year be sustained? The answer from a technical economic point of view (as distinguished from psychological or political perspectives, which I do not address here) is an unambiguous yes. Some argue that the deficit is large beyond all precedent in this country, veering into the "danger range" at which some developing countries have run into payments crises in the past. Some argue that the deficit cannot be sustained because at some point foreigners will cease to be willing to invest enough in the United States, or because the United States will run out of assets attractive to foreigners, or both. Some concede that the deficit might be sustainable at its current level, but maintain that it is on a trend that cannot be sustained. Some judge the deficit to be undesirable even if sustainable, not least on grounds that it permits higher current consumption but bequeaths greater liabilities to future generations. Whether it is desirable or not depends, of course, on the feasible alternatives, not on abstract considerations.

I will try to address quantitatively two questions: whether foreign saving will be adequate to finance a continuing or even a rising U.S. current account deficit, and whether U.S. financial claims of adequate quality will 
Table 1. Hypothetical Investment Flows in a Fully Globalized World Trillions of dollars

\begin{tabular}{lcccccc}
\hline & 2001 & 2002 & 2003 & 2004 & 2005 & 2006 \\
\hline $\begin{array}{l}\text { Actual world saving } \\
\quad \text { (exc. United States) }\end{array}$ & 5.02 & 5.23 & 6.21 & 7.44 & 8.27 & 9.16 \\
$\begin{array}{l}\text { Foreign investment in } \\
\quad \text { United States }\end{array}$ & 1.61 & 1.67 & 1.84 & 2.10 & 2.31 & 2.52 \\
$\quad \begin{array}{l}\text { U. investment abroad } \\
\text { b }\end{array}$ & 1.13 & 1.01 & 1.02 & 1.11 & 1.16 & 1.32 \\
Net inward foreign investment $^{\text {and }}$ & 0.48 & 0.66 & 0.82 & 0.99 & 1.15 & 1.20 \\
\hline
\end{tabular}

Source: Author's calculations based on IMF, World Economic Outlook (April 2007), tables 1 and 43, and World Bank, World Economic Indicators.

a. Assumes that the share of non-U.S. saving invested in the United States would equal the share of the United States in world GDP.

b. Assumes that the share of U.S. saving invested abroad would equal the share of the rest of the world in world GDP.

be sufficient to satisfy potential foreign demand for them. I will also address foreigners' motivation to invest in the United States.

The U.S. current account deficit (which by definition equals net foreign investment in the United States, apart from measurement errors) of $\$ 811$ billion in 2006 was certainly unprecedentedly large. But in fact it was smaller than the deficit that would have resulted if world financial markets were fully globalized, if globalization is taken to mean that savers around the world allocate their saving according to the relative sizes of national economies, without any bias toward domestic investments. Such a "gravity model" approach to world financial flows, of course, involves a vast simplification, but it is an informative starting point.

The results of such a calculation are shown in table 1. The U.S. share of the world economy (at market exchange rates, the relevant measure for this calculation) was 30 percent in 2000, rose slightly in 2001-02, and then declined to 27.5 percent in 2006 . With no home bias, the rest of the world would have invested these shares of its saving in the United States. Americans, by the same token, in 2000 would have invested 70 percent of their saving in the rest of the world, rising to 72.5 percent in 2006. Applying these percentages to actual saving (from the International Monetary Fund's World Economic Outlook) in the rest of the world and the United States, respectively, would have resulted in net foreign investment of $\$ 480$ billion in the United States in 2000, compared with an actual flow of $\$ 380$ billion. Net foreign investment in this simple model would have risen to $\$ 1.2$ trillion in 2006, compared with actual investment of $\$ 811$ billion. So foreign investment in the United States can be expected to rise over time until the slow decline in the U.S. share fully offsets the 
rise in foreign saving, or until U.S. saving rises sufficiently sharply to overcome the annual increases in foreign saving, or until foreign saving falls sufficiently to close the gap.

This calculation takes gross saving as given, and it ignores the impact that actual investment opportunities, through such characteristics as their yield, risk, and liquidity, might have on decisions about how to allocate saving. In this respect it is similar to the gravity models of trade, which focus on economic size and distance and ignore the structure of comparative costs, which are what give rise to the incentives to trade. I now turn to incentives.

\section{Demography and the Saving-Investment Balance}

The net current account surplus of the rest of the world must by definition equal the U.S. current account deficit, apart from measurement errors. This surplus implies an excess in the rest of the world of national saving over domestic investment. Why do such surpluses occur, especially given that many countries run budget deficits, which absorb much of the excess private saving? Part of the answer is that a significant rise in oil prices since 2002 increased government revenue in the oil-exporting countries in the first instance, producing budget surpluses. Much of this saving will be transitory as this revenue enters the domestic income stream, raising private incomes and import demand. However, a number of oil-exporting countries have now emulated Kuwait and Norway in setting aside a portion of their large oil earnings, investing them abroad for the benefit of future generations. Thus significant saving in these countries may endure for many years.

There are many other reasons for high saving, related, among other things, to uncertainty and even insecurity about the future (partly due to memories of past adversity), imperfect arrangements for consumer credit for large purchases, corporate management incentives to retain rather than distribute earnings, and so on. But one factor has received too little attention, and indeed what little notice it has gotten has been misleading. That is the dramatic demographic transformation that many countries are going through. Much has been written about the aging of societies, with appropriate focus on unfunded pension and medical care commitments by governments. But aging is occurring for two quite dif- 
ferent and mostly unrelated reasons: increasing longevity and declining natality.

Longevity in the United States rose by 8.2 years over the past half century, and in Japan it rose by about twice that. When such increases are not accompanied by a corresponding increase in the average retirement age, one can expect to see households increase not only their saving for retirement, but also their precautionary saving, since lives are not only longer but also uncertain in their length. The standard model of life-cycle saving behavior, in which dissaving occurs in one's later years, typically assumes a known, or known expected, time of death. In reality, there is much uncertainty and, thanks to steadily advancing medical technology, perhaps even increasing uncertainty about the time of death. All else equal, this should increase saving, even into retirement, especially in a context of growing uncertainty about the financial viability of many public pension schemes. Americans have heard much about the future problems of their social security system, but public pension schemes in many other countries are in even worse shape.

These effects of increasing longevity are important, but the aging of societies through reduced natality has perhaps an even greater influence on national saving-investment balances, by reducing investment. Low natality implies, over time, declining numbers of young adults, hence fewer new households, hence lower demand for schools, housing, and all the appurtenances associated with housing, such as appliances and furniture. Reduced natality also means less new capital will be required to equip new members of the labor force with the average share of the productive capital stock. In addition, young adults today are on average the most highly educated and most flexible members of the labor force, geographically and occupationally. A decline in their numbers will thus have a negative impact, ceteris paribus, on productivity growth in an era of continuous advances in technology and changes in the composition of demand. Of course, some capital deepening will occur, but that will drive down the domestic return to capital.

Saving rates have dropped in Japan, although less than life-cycle devotees expected. But investment has dropped even more. Private saving in Germany has risen, mostly absorbed by a 4-percentage-point increase in the public deficit between 2000 and 2005, but investment has fallen sharply. A roughly similar pattern has occurred in the newly rich Asian economies. In contrast, investment rose in developing Asia, exceeding 
40 percent of GDP in China by 2005; but saving rose even more in these rapidly growing economies.

Population projections in these countries and others are striking. Most rich countries, along with China, now have a net reproduction ratio below unity; that is, populations are not reproducing themselves. The average number of children per woman of childbearing age is around 1.4 in Germany and Japan, and 1.0 in Hong Kong and Singapore (2.1 children per woman are required to sustain a population in the long run). The populations of Germany and Japan have already peaked, despite increasing longevity, and the number of young adults has been declining for some time, and this will continue.

Among the rich countries, the United States stands out as a strong exception: although birthrates have declined, they remain above 2 per woman, and the U.S. population is being augmented by over a million immigrants a year, who in general are young and over time become well integrated into the U.S. labor force. Table 2 presents U.S. Census Bureau projections of the number of young adults (ages 15-29) in each of the world's largest economies plus four newly rich Asian economies, whose current account surpluses together (when Germany is augmented by its two close economic neighbors, the Netherlands and Switzerland) in 2006 equaled 90 percent of the U.S. deficit. (The surpluses of oil exporters equaled an additional 46 percent of the U.S. deficit. The U.S. deficit in turn equaled 70 percent of total world deficits.) The numbers of young adults declined in absolute terms in China, Germany, Japan, and the four newly rich economies, at a rate of roughly 1 percent a year. The number of young adults in these countries also declined steeply as a share of total population. In the United States, in contrast, the number of young adults is expected to rise slowly over the next two decades, and the actual increase will probably be even greater because of the Census Bureau's conservative assumptions regarding immigration.

China, of course, is in different circumstances from Germany, Japan, and other rich countries. Its rural population, despite having fallen by 20 percentage points of total population over the past two decades, remains large, and therefore much further rural-to-urban migration can be expected. The rapid growth of the urban labor force can be expected to continue, and with it demand for housing, schools, and productive capital stock. Moreover, Chinese incomes have grown rapidly, and this growth can be expected to continue and result in a housing boom, as people not only change loca- 
Table 2. Population Aged Fifteen to Twenty-Nine in Selected Economies, 2005 and 2025

\begin{tabular}{|c|c|c|c|}
\hline \multirow[b]{2}{*}{ Country or group } & \multicolumn{2}{|c|}{ Millions } & \multirow[b]{2}{*}{ Change, 2005-25 (percent) } \\
\hline & 2005 & 2025 & \\
\hline China & 321 & 259 & -19 \\
\hline Japan & 22.6 & 17.8 & -21 \\
\hline Germany & 14.2 & 11.9 & -16 \\
\hline Newly rich Asian economies ${ }^{a}$ & 18.6 & 14.2 & -24 \\
\hline United States & 61.9 & 66.0 & 7 \\
\hline
\end{tabular}

Source: U.S. Census Bureau.

a. Hong Kong, Korea, Singapore, and Taiwan.

tion but also upgrade the quantity and quality of their living space. China's investment rates are high. But with income per capita growing at over 7 percent a year, in the presence of desires for lumpy expenditures and an underdeveloped capital market, Chinese saving rates have increased even as consumption has grown rapidly. Moreover, many Chinese state-owned enterprises have been modernized and downsized, improving their earnings, while others enjoy quasi-monopoly profits. State enterprises in China do not have to pay dividends to their government owners, and therefore as earnings have increased, so have recorded corporate savings.

\section{Why Invest in the United States?}

Given that a number of the largest and richest countries, as well as some poor countries such as China, have excess saving, why does so much of that saving go to the United States rather than to other countries? After all, under simple neoclassical assumptions, excess national saving should flow to those regions of the world where the return to capital is highest, which are assumed to be those where capital is scarce relative to other factors of production, most notably labor but including also arable land and specific natural resources.

Part of the answer is that this widely accepted proposition is a vast generalization, and discerning investors do not invest on the basis of such generalizations, even if economists are comfortable with or, indeed, seem to prefer them. Details are all-important. Security of investment is important, often trumping high yields for many investors, especially those investing for retirement. Recent experience in Argentina, Bolivia, Russia, 
and Venezuela has reminded everyone that private investment, especially by foreigners, is not always secure. Also, in the capital-poorest countries, yields are often low because of strong complementarities between invested private capital and the institutional setting, the latter interpreted broadly as including but not limited to public infrastructure.

Despite these shortcomings, much private foreign capital has gone into developing countries in recent years: over $\$ 500$ billion (net) in 2005, mostly to East Asia and Central Europe. ${ }^{4}$ But this compares with over $\$ 1$ trillion in foreign private funds invested in the United States in 2005, and nearly $\$ 1.5$ trillion in 2006 .

There are several reasons why foreigners might prefer the already capital-rich United States as a locus for investment. One is simply the size of the economy, noted above. Another is that property rights are secure in the United States, and dispute settlement is relatively speedy and impartial. A third is that the United States continues to be a dynamic economy, despite its wealth and maturity, partly because of the demographic features noted above, but also because it is highly innovative and relatively more flexible than other mature economies (and even than many immature ones).

U.S. financial markets are even larger relative to the rest of the world than is its GDP, accounting for over 40 percent of the world's securities (stocks and bonds). In fact, the U.S. share of the world's marketable securities is probably more than half if allowance is made for the fact that many shares of companies in other countries are unavailable for investment, often because they are in government hands. Because of its size and institutional arrangements, many marketable securities are much more liquid in the U.S. market than is true in other financial markets, increasing their attractiveness to passive investors. The U.S. market also offers a wide array of financial assets of differing risk characteristics.

Finally, yields on U.S. debt instruments have recently been higher than those on similar instruments in many other rich countries, notably Japan and continental Europe. Yields have been still higher in Britain and Australia, which share some of the other characteristics of the United States. It is perhaps not a coincidence that net foreign investment has also been high in those countries in recent years.

Foreign portfolio investment in the United States is overwhelmingly denominated in U.S. dollars; indeed, it simply represents purchases of

4. World Bank, Global Development Finance 2007. 
U.S. domestic instruments by people or institutions who happen to reside abroad. Most of these investors therefore bear exchange rate risk. Does this risk not overwhelm the favorable yield differential? Apparently not. One possible reason is that foreign investors are not conscious of the exchange rate risk they are running. But this seems extremely unlikely, given that most of the investors are sophisticated financial institutions, and that economists have been unsparing in pointing out the risks, which have thus had more than adequate publicity.

It must be that foreign investors find the characteristics of their U.S. investments sufficiently attractive to overcome the exchange risks. They may also discount the risk, perhaps because they see little reason to expect movements in exchange rates large enough to negate the yield differential. They may take this view either because they implicitly accept the structural reasons developed above for believing the large U.S. current account deficits to be sustainable, or for some other reason. For example, they may believe that any large exchange rate movement would be sufficiently damaging to elicit countervailing action by the monetary authorities in the affected countries. Of course, after the fact they may be shown to have been wrong in all of these possibilities.

Much has been made of the fact that some of the financing of the U.S. current account deficit has come from central bank purchases of dollardenominated assets. Is this evidence that something other than the attractiveness of U.S. yields is driving these flows? Not necessarily. Arguably, in some of these cases, central banks are simply acting as financial intermediaries on behalf of their aging publics, who either choose not to or are not permitted to invest directly abroad. In any case the inflow of funds to the United States remains overwhelmingly private in origin (if not always in beneficial ownership): private flows were over three-fourths of the totals in 2005 and 2006.

\section{How Long Can the United States Provide Assets for Purchase?}

What about the outlook for investment opportunities in the United States? Will foreigners soon acquire so many U.S. assets that their availability will be exhausted? Not anytime soon. It is useful first to examine some simple debt dynamics and then look at the relationship of U.S. external indebtedness to the availability of U.S. assets. 
The cumulation of current account deficits affects a country's net international investment position (NIIP). Let $D$ represent NIIP, $Y$ output (GDP), $r$ the net return on $D$, and $B$ the deficit in trade in goods and services (excluding investment income) plus unilateral transfers. Then $d D=B+r D$. Stabilizing $D$ relative to GDP $(D / Y)$ implies that $d D / D$ equals growth in nominal GDP. If growth in nominal U.S. GDP in the coming years is assumed to be 5 percent, then a stable $D / Y$ would require that $B / D+r=0.05$.

At the end of 2006, the NIIP of the United States was \$2.2 trillion, or 16 percent of U.S. GDP. ${ }^{5}$ The current account deficit, as mentioned before, was around 6 percent. These numbers suggest little prospect of stabilizing $D / Y$ anytime soon, if ever, even if interest payments to foreigners are low. It looks as though the U.S. deficit may not be sustainable, or that it can be sustained only if $r$ is negative.

In fact, to date $r$ has been negative, since recorded earnings on U.S. investments abroad have continued to exceed foreign earnings on investments in the United States despite a negative NIIP since the late 1980s. Moreover, total returns on foreign investments substantially exceed recorded earnings, and the gap favoring the United States has been even larger, thanks mainly to increases in market values and, to a much lesser extent, depreciation of the dollar. Thus, although the cumulative U.S. current account deficit over 1990-2006 was \$5.21 trillion, the increase in the net debtor position of the United States, at \$2 trillion, was less than half that. The average annual total return on U.S. investments abroad since 1990 (including exchange rate effects, discussed below) was 10.0 percent, compared with a total return of 6.2 percent on foreign investments in the United States. The main reason is that equity investment, both direct investment and portfolio equity, makes up a substantially larger share of U.S. claims on the rest of the world (61 percent) than of foreign investments in the United States (35 percent). Americans act in effect as risk-taking intermediaries in the world economy, selling fixed-interest claims and investing in equity; they thus earn an equity premium in the world economy.

In addition, changes in exchange rates affect valuations when U.S. claims on foreign assets are converted into dollars, in which the U.S. NIIP is reck-

5. The NIIP here and below values inward and outward direct investment at market values as estimated by the Bureau of Economic Analysis rather than at historic or current cost. Financial derivatives are excluded. 
oned. Most U.S. assets abroad are denominated in other currencies, whereas most foreign claims on the United States are denominated in dollars. When the dollar depreciates against other currencies, U.S. claims rise in value relative to foreign claims, and vice versa when the dollar appreciates.

These combined valuation effects can be substantial. In 2005 the U.S. current account deficit was $\$ 755$ billion, but the NIIP actually increased by $\$ 200$ billion. (Reversals in sign also occurred in 1999 and 2003.) The deficit of $\$ 811$ billion in 2006 produced no change in the NIIP, on preliminary figures. Remarkably, the ratio of the NIIP to GDP declined from over 23 percent in 2001 to less than 17 percent in 2006, despite large and growing U.S. current account deficits during this period. Indeed, $D / Y$ was only 4 percentage points of GDP higher in 2006 than eight years earlier, despite a cumulative current account deficit of 38 percentage points of GDP. The dollar depreciated on balance over this period, and the NIIP would have equaled 19 percent of GDP at the end of 2006, or 2.6 percentage points higher than it was, if the dollar had not depreciated. Most of the valuation changes, in other words, were not due to exchange rate changes.

The ratio of the U.S. NIIP to GDP is far below where it would be in a world without home bias, as described above, where foreigners would hold nearly 30 percent of their assets in the United States (over twice the ratio they currently hold). On these grounds, then, the NIIP could still rise significantly.

How much of the United States do foreigners own? Here it is necessary to look at gross foreign investment in the United States, before netting it against American investment abroad. Total foreign claims on the United States at end-2005 were $\$ 11.1$ trillion (including only the net position of U.S. banks), equal to 89 percent of GDP during that year and roughly the same percentage of the private nonresidential fixed capital stock. Total foreign claims then grew to $\$ 13.6$ trillion by the end of 2006 , much faster than GDP. The share of foreign ownership has increased steadily for the past two decades. But foreigners do not generally invest in the domestic capital stock, and their share of ownership of U.S. assets is not rising nearly as rapidly as one might suppose based on the dollar values alone. A remarkable feature of the U.S. economy is that the total value of financial assets has risen significantly more rapidly than the underlying economy. The Federal Reserve estimates total financial assets in the U.S. economy at the end of 2006 to have been $\$ 129$ trillion (this figure is of course sensitive to the system of classification used in the flow of funds accounts, 
and does not include derivatives), or 9.7 times 2006 GDP. Forty years earlier, in 1965, total financial assets were only 4.8 times GDP. Put another way, while nominal GDP grew by 7.4 percent a year over 1965-2006, total financial assets grew by 9.2 percent a year.

This phenomenon reflects, among other things, innovation by the financial sector, which has devised a host of new financial instruments to appeal to a wider variety of circumstances and tastes. This articulation of financial assets appeals to many foreigners as well as to Americans, and foreigners invest in a wide array of these instruments. So although the stock of gross foreign investment in the United States exceeded GDP in magnitude in 2006, it amounted to only 12 percent of total financial assets in the United States. The share has risen from 3 percent in the mid-1980s, but the rise has been slow.

Total financial assets include claims by one sector on another. Ultimately, the U.S. economy is "owned" by households in the United States, plus nonprofit organizations (churches, foundations, universities, etc.), plus foreigners. The foreign share of financial assets owned by these parties (after netting out intersectoral claims) grew from 7 percent in 1980 to 14 percent in 2000 to 15 percent in 2006. This ownership represents claims on future output of the U.S. economy. It remains well below the level of foreign ownership that would obtain in a "no home bias" world. It also remains below levels of foreign ownership (relative to GDP) that have been reached in many other countries, including Australia, Britain, France, Germany, Italy, and Spain. So although the foreign-owned share of U.S. financial assets cannot grow without limit, it can grow for many years before it begins to strain the American capacity to provide financial assets.

\section{Should We Worry about the U.S. Current Account Deficit?}

Viewed in the context of globalization and demographic change in other rich countries, the large U.S. current account deficit is both comprehensible and welfare-enhancing from a global point of view, reflecting intertemporal trade, so long as Americans invest the funds productively. Prospective retirees around the world are making investments in the United States that are profitable and secure. If this is so, strong governmental efforts to reduce the current account deficit might be deeply misguided at best, and run a serious risk of precipitating the financial crisis or economic recession that proponents of such action hope to forestall. 
Not so long ago it was argued that, as a rich country, the United States should be running a current account surplus, not a deficit. More recently it has been suggested that, to achieve sustainability, the deficit needs to be reduced to no more than around 3 percent of GDP from the current 6 percent. Reduction of the deficit by 3 percent of GDP would require that U.S. expenditure also drop, relative to output, by 3 percent of U.S. GDP, or roughly 1 percent of GDP in the rest of the world. Foreign surpluses, taken together, would have to decline by 3 percent of U.S. GDP, implying a rise in demand relative to output by that amount elsewhere in the world.

It is also usually said that, to bring about the required substitutions in product demand, the dollar must depreciate, and probably significantlyperhaps by 30 percent on a trade-weighted basis. So the additional demand in the rest of the world must be domestic demand. For export-oriented economies such as Japan, Germany, and China, currency appreciation is likely to discourage, not encourage, productive investment. So the additional demand must come from domestic consumers or governments. But many governments have been concerned about excessive budget deficits in recent years and are engaged in fiscal consolidation. This is especially true for Japan and Germany, two countries with large current account surpluses. That leaves consumers. What will induce aging consumers outside the United States to spend more? Easier monetary policy, which in Euroland is outside the control of national governments, would in a world of high capital mobility tend to weaken currencies, not strengthen them. The prescription must therefore combine stimulative fiscal policy with tighter monetary policy and currency appreciation. Yet Europe's mid-term policy focus, reflected in the Lisbon agenda of 2000, has on the contrary been on fiscal consolidation plus measures to improve productivity and output, resulting (as explicitly desired) in greater international competitiveness, not greater domestic demand.

China, which controls its exchange rate, could decide to revalue substantially, as many have urged. But even if China were to eliminate its current account surplus entirely, only a fraction of the resulting reduction in global imbalances would accrue to the United States, as U.S. imports from China would largely switch to other low-income countries. That would still leave a U.S. current account deficit in excess of the targeted level. Moreover, what would an appreciation large enough to eliminate China's surplus do to China's economy, where exports of manufactures 
containing mostly imported inputs have led growth? True, exports have not been China's only source of growth in demand. Public and private construction has boomed, and Chinese consumption grew in excess of 8 percent a year during 1989-2005, faster than anywhere else in the world. But exports have been the driving sector.

The argument developed here suggests that the U.S. current account deficit can continue for some years and even widen. Of course, a significant depreciation of the dollar might nevertheless occur. Financial markets are driven by psychological as well as by economic factors. If enough people decide to sell dollars, the dollar will depreciate. Or if foreigners collectively decide to invest less in the United States than the current account deficit (plus American capital outflow), the dollar will depreciate.

A large drop in the dollar would have grave economic consequences, reducing exports and depressing investment in other rich countries. For this reason, their monetary authorities are likely at some point to intervene in foreign exchange markets to limit the resulting downturn, in effect substituting official for private capital investment in the United States and thereby putting effective limits to any depreciation of the dollar.

But, of course, the current account deficit cannot rise indefinitely relative to GDP, nor can foreign-owned assets rise indefinitely as a share of total U.S. assets. Sooner or later the process of financial globalization will slow and eventually stop, probably well before the hypothetical state of "no home bias" is reached. Moreover, aging societies will eventually reach the point at which they cease acquiring new foreign assets and begin to liquidate their outstanding claims. Then the U.S. deficit must decline, perhaps significantly. The trade deficit will need to decline even earlier, as foreigners begin to consume the earnings on their U.S. investments. But that point may not be reached for a decade or longer, especially if people work longer and continue to save past the conventional retirement age, as many do.

As Asians and Europeans begin to consume their overseas earnings and the underlying assets, total expenditure in their countries will rise relative to output, and their current account surpluses will decline and eventually disappear. This process alone will help reduce the U.S. deficit, without any depreciation of the dollar against their currencies. To what extent the dollar needs to depreciate will depend on the emerging consumption patterns in the aging societies, and in particular on the mix between tradable and nontradable goods and services, keeping in mind that these categories are themselves constantly changing, as increased possibilities for offshoring 
push more nontradables into the tradables category. Even nontradables can enter the international accounts insofar as they are provided by temporary migrant workers who remit earnings to their home countries. Elder care is likely to involve both processes, with diagnoses performed in remote locations and treatment provided by migrant workers in situ, as the children and grandchildren and great-grandchildren of the aged choose to stay in the labor force.

Another possibility involves Asians and Europeans retiring in the United States, just as some Canadians do now. Their assets would then cease to be foreign claims on the United States.

The adjustment process involves the classic transfer problem in a more complex setting. How much, if at all, the dollar needs eventually to depreciate will depend on all of these factors, and certainly cannot be foretold years in advance of the required adjustment.

The United States has a vibrant, innovative economy. Its demographics differ markedly from those of other rich countries, in that birthrates have not fallen nearly so far and immigration, concentrated among young adults, can be expected to continue on a significant scale. In these respects the United States, although rich and politically mature, can be said to be a young and even a developing country. It has an especially innovative financial sector, which continually introduces new products to cater to diverse portfolio tastes. The United States has a comparative advantage, in a globalized market, in producing marketable securities and in exchanging low-risk debt for higher risk equity. It is not surprising that savers around the world want to put a growing portion of their savings into the U.S. economy. The U.S. current account deficit and the corresponding surpluses elsewhere, although conventionally described as imbalances, do not necessarily signal economic disequilibria in a globalized world economy, and they may well remain large for years to come.

\section{References}

Cline, William R. 2005. The United States as a Debtor Nation. Washington: Institute for International Economics.

Corrado, Carol A., Charles R. Hulten, and Daniel E. Sichel. 2006. "Intangible Capital and Economic Growth.” Working Paper 11948. Cambridge, Mass.: National Bureau of Economic Research (January). 


\section{General Discussion}

William Nordhaus agreed with Richard Cooper that saving is understated in the national accounts, but he noted some improvements in this area, such as the addition of software spending to investment and output in the core accounts, the creation of a satellite account for research and development, and ongoing work to create a satellite account for education. Nordhaus wondered why Cooper used gross rather than net saving and investment. For most countries net investment is much smaller than gross, and the current account is a net saving concept. Cooper replied that gross saving and investment are the relevant concepts because firms do not distinguish between depreciation allowances and other sources of internal funding, but instead treat all investments in the same manner based on an assessment of their profitability.

Charles Schultze suggested that the magnitude of Cooper's adjustments to saving and investment was overstated. For example, including advertising makes some sense because it provides information to consumers, but it also creates negative externalities for other firms, as one firm's gain is another firm's loss. Similarly, recent large increases in aggregate public spending for elementary and secondary education have not had a large payoff. From 1974 to 2004, real per pupil spending for public K-12 education doubled, but the performance of seventeen-year-olds on national assessment tests in math and reading was more or less flat. Competition regulates rates of return on private investment, but the same is not true for public education. Schultze added that the same problems apply to many other government investments, such as highways and flood control infrastructure. Because no method exists for properly determining the scale and allocation of these investments, the relationship between the money spent and the return is complicated. 
William Gale added that including additional forms of saving raises the estimated level of saving but does not reverse its decline over time. Gale also wondered how much the analysis of the U.S. current account deficit changes if Americans' foreign borrowing is mostly done for consumption rather than for investment. Similarly, he wondered how the analysis changes if investment from abroad is composed more of foreign central banks buying Treasury bonds than of foreign private investors buying real assets. Cooper replied that inflows to the United States are overwhelmingly private. In fact, he noted, even official flows are often mediated private flows: In Japan, for example, where large quantities of domestic savings are conservatively held in domestic banks, the central bank invests some of these assets in foreign markets in order to meet the country's retirement needs.

Olivier Blanchard suggested that uncertainties about the factors supporting the current capital inflow to the United States tilt heavily toward a reduction in that inflow in the future: foreign official purchases seem more likely to decline than to increase, the institutional setting for investments in other countries is likely to improve, recent declines in the value of the dollar are likely to heighten perceptions of exchange rate risk, and America's role as a risk-taking financial intermediary in the world economy may backfire.

Martin Feldstein pointed out that the real foreign exchange value of the dollar has dropped about 15 to 20 percent over the last five years, depending on the measure used. Therefore the current account deficit should decline further, and he wondered about the implications for Europe and other countries. To avoid recession in their countries, he suggested, foreigners will have to increase their consumption by 2 or 3 percent of their GDP, which may be possible given their current high saving rates.

Robert Gordon emphasized that differences in asset returns and changes in the value of the dollar have prevented an explosion of U.S. net international indebtedness so far: U.S. net debt to foreigners was the same fraction of GDP in 2006 as it had been in 2001 (19 percent), despite a cumulative current account deficit of 30 percentage points of GDP over this period. Robert Lawrence pointed out that receipts on U.S. assets abroad exceed payments on foreign assets in the United States by about $1 / 4$ percent of GDP, the same as twenty years ago. Given that the burden has not increased-partly because of the different mix of investments here than abroad-it is difficult to argue that the current position is unsustainable. Lawrence added that the demographic factors described in the paper were interesting, but the same 
factors are more pronounced in Europe, yet Europe's capital account is basically balanced, so there must be more to the story.

Cooper emphasized that he did not consider the current imbalance a "steady state," nor did he expect it to last forever. Still, he did expect imbalances to persist for a decade or more. Eventually, retirement in Japan and Germany will exhaust savings in these countries, and current account positions will change. 